\title{
Marketing of Dried Swim Bladder of Fishes (Vesica Natatorium) in or on Local Government Area, Akwa Ibom State, Nigeria
}

\author{
Namso N Frank, Ubokudom E Okon* and Itohowo S Nkebe \\ Department of Agricultural Economics and Extension, Akwa Ibom State University, Nigeria
}

*Corresponding author: Ubokudom E Okon, Department of Agricultural Economics and Extension, Akwa Ibom State University, Nigeria.

To Cite This Article: Namso N Frank, Ubokudom E Okon, Marketing of Dried Swim Bladder of Fishes (Vesica Natatorium) in or on Local Government Area, Akwa Ibom State, Nigeria. Am J Biomed Sci \& Res. 2019 - 6(3). AJBSR.MS.ID.001039. DOI: 10.34297/AJBSR.2019.06.001039.

Received: 阱 November 2, 2019; Published: 眥 November 26, 2019

\begin{abstract}
This study examined the marketing of dried fishes swim bladder (vesica natatorium) in LGA, Akwa Ibom State, Nigeria. It examined the socioeconomic characteristics of marketers, characterized and documented the preferred fishes, estimated the cost and profitability and analyses the constraints to marketing. Descriptive statistics, characterization and documentation research, budgetary analysis and simple ranking models were used respectively. The research results show that $51.67 \%$ of the traders were aged $31-40$ years while $80 \%$ of them were married, $55 \%$ had household size of 4-6 persons and 50\% had primary education. 53.33\% of them apiece have 5-10 years trading experience with petty trading as their secondary occupation while 55\% made a monthly income N21,000-N30,000. Field survey shows that only cartilaginous fishes swim bladders were preferred. Budgetary analysis of Fixed Cost (FC) marketing shows that shop rent was 9.35\% of the Total Cost (TC) and 41.60\% of the Total Fixed Cost (TFC). It was followed by refrigeration/power. Analysis of variable cost marketing shows that fish price has the highest percentage of both the TC and the Total Variable Cost (TVC) of marketing. The FC and TVC was only $22.47 \%$ and $77.53 \%$ of the TC respectively. Profitability analysis gave total revenue of $\$ 3,413,591.00$, net profit of $\$ 889,001.00$ and marketing efficiency of 135.2 for the period. However, it was constrained by lack of storage facilities, poor marketing channels, high cost of drying, price fluctuation, etc. It recommends that the constraints should be addressed for effective and efficient marketing of the product.
\end{abstract}

\section{Background of Study}

In the last two decades, there has been a land slide movement towards markets liberalization in the world. Although the pace and depth of liberalization have varied both in international and domestic markets, but no continent remains untouched [1]. Though, this movement differs remarkably across sectors and countries, $\mathrm{Ni}$ geria is not an exception. One of the sectors that have experienced this enormous market liberalization in Nigeria is the fishery sector. This has enabled untold exploitation of not only the fishes but its bye and processed products.

As a maritime nation is rich in virtually all the fisheries resources that could be found around the world (International Fund for Agricultural Development/Agricultural Development-Community Based Natural Resource Management Project [2], thus making captured fishing an important economic activity in Nigeria. Apart from the nutritive value of whole fishes (either fresh or dried) which its acclaimed usefulness has been acknowledged, fishes are made up of different marketable parts which have other very important economic and medicinal values. One of such important part is the swim bladder or air sacs - a buoyancy organ possessed by most cartilaginous fishes.

The air sacs or swim bladder is in the body cavity and is derived from an out pocketing of the digestive tube. It contains gas (usually Oxygen) and functions as a hydrostatic or ballast organ, enabling the fish to maintain its depth without floating upward or sinking. It also serves as a resonating chamber to produce or receive sound. In some species the swim bladder contains oil instead of gas. In certain primitive fishes, it functions as a lungs or respiratory aid instead of a hydrostat organ. The swim bladder/air sac is missing in some bottom-dwelling and deep-sea bony fish (teleosts) but present in some cartilaginous fish (sharks, skates, and rays) [3].

These air-sacs gotten from these preferred cartilaginous fishes are soft jelly-like wetted organ. They are processed by sun drying for a period of 2-3 day depending on the intensity of the sun. The 
possessed air sacs are sorted depending on the size which invariably denotes the size of the fish processed from. They are then after, graded, packaged and weighed. The buyers are contacted, and the bargain is done based on the grade. Though, the usefulness of these processed air sacs has not been authenticated, a marketer who preferred anonymity alleged that there are used for the manufacturing of medical surgery sutures. This, the author seems to believe because most bio-degradable sutures are product from animals' intestines (Encyclopaedia Britannia) and the fact that the buyers emphasizes preservation of the products by sun drying.

Extant literature reports that cat-gut or gut suture is an absorbable suture usually manufactured from the intestine of sheep or goats. They are composed of highly purified connective tissue derived from both beef or sheep intestines and have the capacity for absorption within 60-90 days for chromic sutures, 60-70 days for plain gut sutures with it full tensile strength remaining for at least 7 days. Because they eventual disintegration it makes it good for use in rapidly healing tissues and in internal structures that cannot be re-accessed for suture removal (Wikipedia, 2012). They are good for general closure, ophthalmic, orthopedics, obstetrics, gynecology and gastro/intestinal tract surgery [4]. Air sacs supply and marketing thrives in Oron Local Government Area of Akwa Ibom State. However, due to the cumbersome nature of fish distribution channel and the value given to the preferred cartilaginous fishes, the local dry air sac marketers must be tenaciously connected to enable easy assessment of the fishes and disposal of their products. This system may not be without some setbacks which need to be addressed for smooth, effective and efficient.

\section{Statement of Problem}

In spite of the paradigm shift from raw agricultural produce/ farm gate sales to the current glamour for complete value chain exploitation of agricultural product for effective and increase returns, certain agricultural processed products until this twenty first $\left(21^{\text {st }}\right)$ century have neither been given comprehensive documented or its versatile usefulness investigated. One of such products is processed air sacs of some cartilaginous fishes also called swim bladder or "flooters" as fondly referred to by the local people of Oro Nation. The air sac or swim bladder is a structure in the fishes - a sac that grows out from the anterior part of the gut. Fishes use it for self-buoyancy controls and gills for respiration. This deduction is made on grounds that cartilaginous fishes are almost exclusively water breathers at $10^{\circ} \mathrm{C},\left(50^{\circ} \mathrm{F}\right)$, a temperature they show low physical activity and air breathing rate is said to be directly proportional to temperature and activity.

The generally accepted explanation of the use of this singular organ is that it serves to enable the fish to readily rise and sink in water. These important organs of the fishes are also processed and sold differently and are alleged to be used for making medical sutures and glass-fibre engine boat repairing. Other literature documentation has it that in some Asian cultures, swim bladders of certain large fishes are considered a food delicacy. Specifically, in China, they are known as fish maw, and are served in soups or stews [5]. So important and valuable are these organs that Vaquita Recovery Team [6] reported that; "the vanity price of a maw is behind the imminent extinction of the vaquita -the world's smallest dolphin breed found only in Mexico's Gulf of California and that the air sacs (maw) of totoaba (the world's largest drum fish) sells for as much $\$ 10,000$ per kilogram". Swim bladders have also been reported to be used in the food industry as a source of collagen. They can be made into strong, water-resistant glue, used to make isinglass for the clarification of beer and in earlier times they were used to make condoms [7].

Within the coastal settlement and towns of Akwa Ibom State, the marketing of dried air sacs (flooters) is on-going and the marketers are flourishing. However, this business is missed in economic literature. It is against this backdrop that this study is set to bridge the gap in terms of literature and knowledge concerning marketing of processed dried swim bladders. This research is to analysis the marketing of selected fishes processed air-sacs in Oron Local Government Area, Akwa Ibom State, Nigeria.

The research questions posed are:

a) What are the socio economics characteristics of the marketers of dried air sacs of fishes?

b) What are the preferred fish types for marketed air sacs in Oron LGA, Akwa Ibom State?

c) What is the estimated cost, revenue, gross margin and net profit of marketed air sacs?

d) What are the constraints of dried fish air sacs marketing?

Objectives: The broad objective of the study is to analyses the marketing of selected fishes processed air-sacs in Oron Local Government Area, Akwa Ibom State, Nigeria.

The specific objectives are to:

a) Examine the socio economics characteristics of the marketers;

b) Document and characterize the preferred fish types for marketed air sacs in Oron LGA;

c) Estimated cost, revenue, gross margin and net profit of marketed air sacs and;

d) Examine the constraints of dried fish air sacs marketing.

\section{Materials and Methods}

\section{Study area}

This study was carried out in Oron Local Government of Akwa Ibom State. Oron is in the South-Eastern fringe of Akwa Ibom State, bordered in the South by Ibeno and the Atlantic Ocean, in the West by Esit Eket and Nsit Ubum in the North, by Nsit Atai and Uruan and 
in the East by cross River estuary. Covering a geographical area of approximately 45.135 square Kilometers, it is located approximately on latitude $4^{0} 42^{\prime} \mathrm{N}$ and longitude $8^{0} 10^{\prime} \mathrm{N}$. According to the 2006 population census, Oron local Government Area has a population of 87,461 people with polar coordinates of $351.756305694580079^{\circ} \mathrm{W}$ and $8.243694305419921^{\circ} \mathrm{E}$. The major occupations of the inhabitants include fishing, farming, and petty trading. Crops grown include cassava, maize, yam, okra etc. The women folk are mainly into fish processing and petty trading. Fish processing is mainly by smoking however fresh air sacs is preserved by sun drying. This might relate to the preservation of the inherent nature of the product. Others include farming and rearing of animals.

\section{Sampling procedure and data collection}

Purposive sampling technique was used to select sixty respondents. The sixty (60) respondents of dried fish air sac trade were used for the analysis. The reason for the purposive sampling technique was since the business at the study area is shrouded in secrecy. Equally, there is no shop that displays the product as it is done for other goods. Thirdly, only those that were ready to volunteer information were approached. Primary data collected using structured questionnaires administered by enumerators were used. The questionnaires were pre-tested for construct and validity. Key Informant Interview was used to elicit information about the preferred fish types of marketed air sacs and to characterize the sources and arrangement for the preferred fish types. Secondary data was used to complement the information.

\section{Methods of data analysis}

The social and economic characteristics of respondents were analyzed using descriptive statistics. These included mean, proportions and percentages. Characterization and documentation were used for preferred fish type. Budgetary analysis was employed to

\section{Results}

\begin{tabular}{|c|c|c|c|}
\hline $\mathrm{S} / \mathrm{N}$ & Variables & Freq & $\%$ \\
\hline \multirow{7}{*}{1} & Age & & \\
\hline & $21-30$ & 17 & 28.33 \\
\hline & $31-40$ & 31 & 51.67 \\
\hline & $41-50$ & 9 & 15 \\
\hline & 51 and above & 3 & 5 \\
\hline & No Response & 0 & 0 \\
\hline & Total & 60 & 100 \\
\hline \multirow{7}{*}{2} & Marital Status & & \\
\hline & Single & 8 & 13.33 \\
\hline & Married & 48 & 80 \\
\hline & Divorced & 1 & 1.67 \\
\hline & Widow/Widower & 3 & 5 \\
\hline & No Response & 0 & 0 \\
\hline & Total & 60 & 100 \\
\hline
\end{tabular}

estimate the cost, revenue, gross margin and net profit accruable to the dried fish air sac marketers.

The equation used in estimating the gross margin is defined below:

$\mathrm{GM}=\mathrm{TR}-\mathrm{TVC} \quad-\quad-\quad-$

Where:

$\mathrm{GM}=$ Gross Margin, $\mathrm{TR}=$ Total Revenue and TVC $=$ Total Variable Cost

The equation used in ascertaining the net profit is as follows:

Л $=\mathrm{TR}-\mathrm{TC}-$

Where:

$\Omega_{1}=$ Profit

$\mathrm{TR}=$ Total Revenue

$\mathrm{TC}=$ Total marketing Cost

The efficiency of marketing was measured by Shepherd-Futrel model as shown:

$$
\begin{aligned}
& M E=\frac{T R}{T C} \times 100 \\
& \frac{T R}{T V C}>0=\text { It is operational ef } \\
& \text { Where: } \\
& \text { ME = Marketing Efficiency } \\
& \text { TC }=\text { Total marketing Cost } \\
& \text { TR }=\text { Total Revenue }
\end{aligned}
$$$$
\frac{T R}{T V C}>0=\text { It is operational efficiency }
$$
der of severity. One (1) was considered the most severe constraint while rank 10 was the least severe constraint.
Constraints to dried fish air sacs marketing will be ranked in or- 


\begin{tabular}{|c|c|c|c|}
\hline \multirow{5}{*}{3} & Household Size (Persons) & & \\
\hline & $1-3$ & 25 & 41.67 \\
\hline & $4-6$ & 33 & 55 \\
\hline & $7-10$ & 2 & 3.33 \\
\hline & Total & 60 & 100 \\
\hline \multirow{7}{*}{4} & Educational Level & & \\
\hline & No formal education & 8 & 13.33 \\
\hline & Adult Education & 3 & 5 \\
\hline & Primary Education & 30 & 50 \\
\hline & Secondary Education & 17 & 28.33 \\
\hline & Post-Secondary Education & 2 & 3.33 \\
\hline & Total & 60 & 100 \\
\hline \multirow{7}{*}{5} & Experience (Years) & & \\
\hline & 10-May & 32 & 53.33 \\
\hline & $15-\mathrm{Nov}$ & 19 & 31.67 \\
\hline & $16-20$ & 9 & 15 \\
\hline & above 20 & 0 & 0 \\
\hline & No Response & 0 & 0 \\
\hline & Total & 60 & 100 \\
\hline \multirow{7}{*}{6} & Occupation & & \\
\hline & Petty Trading & 32 & 53.33 \\
\hline & Sea food Trading & 19 & 31.67 \\
\hline & Civil Services & 5 & 8.33 \\
\hline & Farming & 3 & 5 \\
\hline & Fishing & 1 & 1.67 \\
\hline & Total & 60 & 100 \\
\hline \multirow{8}{*}{7} & Monthly Income & & \\
\hline & N 1000:00- N 10000:00 & 2 & 3.33 \\
\hline & N 11000: $00-\mathrm{N} 20,000: 00$ & 12 & 20 \\
\hline & N 21,000:00 - N 30,000:00 & 33 & 55 \\
\hline & N 31,000:00 - N 40,000:00 & 5 & 8.33 \\
\hline & $\mathrm{N} 41,000: 00$ - $\mathrm{A} 50,000: 00$ & 4 & 6.67 \\
\hline & More than N 50,000:00 & 4 & 6.67 \\
\hline & Total & 60 & 100 \\
\hline
\end{tabular}

Table 1 indicates that the dominant age of marketers is 3140years. This group made up of $51.67 \%$ of the respondents. This is followed by those in the age group of 25-30 years which make up $28.33 \%$ of the respondents. Those within the age limit of 41-50 years are next in descending order. The study reveals that most of the dried fish's air sac marketers are within the active and productive years 21-40 years (80\%). The engagement of young people in dried fish's air sac marketing may be as a result of lack of white-collar jobs in the Federal and State ministries and the quest to meet financial obligations.

Marital Status indicates that majority of dried fish's air sac marketers in the study area are married. This group made up of $80 \%$ of the respondents, followed by the single which make up $13.33 \%$, the divorcees make up of $1.67 \%$ while the widows /widowers constituted 5\%. The study reveals that most of the dried fish's air sac marketers are married and with children which must be taken care of. This connotes the engagement of household heads on whatever work for the survival of the family. The result of household size indicates that $55 \%$ of the respondents have 4- 6 persons per household. This is followed by those with a household size of 1-3 persons $(41.67 \%)$ and lastly by those $7-10$ persons $(3.33 \%)$ per household in that order. The study reveals that most of the respondents are lettered and this may reflect the advocacy of family planning and in-between children spacing campaign. 
Educational attainment shows that $50 \%$ of the respondents have at least attended primary school. While 33\% of them have at least attended secondary school and those with no formal education is just $13.33 \%$ of the respondents. However, the study shows that $3.33 \%$ of them have higher educational qualification (NCE, OND, HND and or Degree). The study reveals that majority of the dried fish's air sac marketers are lettered and education being the bedrock of development has redefined the dried fish's air sac business relationship in the study area. Marketing experience shows that $53.33 \%$ of the respondents have at least 5-10 years of experience, $31.67 \%$ of them have $11-15$ years of experience while $15 \%$ of them have 16-20 years marketing experience. The study reveals that majority of the dried fish's air sac marketers are young experience marketers and these is expected to translate into dynamic marketing.

Occupation of the respondents indicates that $53.33 \%$ of the respondents are into petty trading, $31.67 \%$ of them are Sea food trading. This is expected because all the area and adjoining Local Government Areas (Mbo, Udung Uko, Okobo and Uruefong/Oruko) are surrounded by water. The civil servants are only $8.33 \%$ of the respondents, whereas the farmers and fishermen amongst them constitute $5 \%$ and $1.67 \%$ of the respondents respectively. The study reveals that majority of the dried fish's air sac marketers are traders and dried fish's air sac marketing business relationship need some capital.

Monthly income analysis shows that $55 \%$ of the respondents made $\$ 21,000: 00-\$ 30,000: 00$ per month from dried fish's air sac trading. Those who make 11000 :00-\$20,000:00 monthly income is $20 \%$ of the respondents while $8.33 \%$ of them make $\$ 31,000: 00-\$ 40,000: 00$ monthly income. Those that make $\$ 41,000: 00-\$ 50,000: 00$ monthly income is only $6.67 \%$ and those on $\mathrm{N1}, 000: 00-\mathrm{N} 10,000: 00$ monthly income is only 3.33\%. It also shows that $6.67 \%$ of the respondents make more than N50,000 from the trade. The study reveals that about $23.33 \%$ of the dried fish's air sac marketers make monthly income of less than $¥ 18,000.00$ which is the Federal government approved national minimum wage.

\section{Characterization of Preferred Fish Types for Marketed Dried Air Sacs}

Field survey shows that cartilaginous fishes are the preferred fish type for air sacs in the study area. However, it is imperative to distinguish between them and state why the bony fishes are not preferred. Technically, the most obvious disparity between bony and cartilaginous fish comes from the fact that the skeleton of bony fish is made of bones alone, while that of cartilaginous fish is made of cartilage. This category of fish is also referred to as Teleostomi. It is also considered the largest class in Phylum Chordata and predominantly found in fresh waters. The cartilaginous fish category is also referred to as Elasmobranchi. This category is primarily made up of marine fishes. Cartilaginous fish (Chondrichthyes) have a skeleton made from cartilage instead of bone. Cartilage is tough and flexible and provides enough structural support to allow these fish to grow to very large sizes. Cartilaginous fish include sharks, rays, skates and chimaeras. Cartilaginous fish all breathe through 5 to 7 gills, depending on the species. In general, open water (pelagic) species must keep swimming to keep oxygenated water moving through their gills whilst bottom-dwelling (demersal) species can actively pump water in through their spiracles and out through their gills.

They generally possess the following characteristics:

a) Their endoskeleton is primarily made of cartilage.

b) Their exoskeleton is made of placoid (very small denticles coated with lots of sharp enamel).

c) The buccal cavity of these fishes is ventrally positioned.

d) The position of their tail fins is heterocercal.

e) On either side, they have five gills that are overly exposed, so they do not have an operculum.

f) Their mode of fertilization is through internal mechanisms.

Among these species are the Rays and skates. Most rays and skates live on the bottom of the ocean while some live-in open water. Some rays also live in freshwater. The manta ray (Manta birostris) feeds on plankton and small fish is the largest ray reaching up to 9 meters in width and can weigh several tones. The common skate (Dipturus batis) is the largest skate in the world, reaching up to 2.5 meters in length with a life span of about 50 years. The major difference between rays and skates is how they reproduce. Fertilization is internal for both rays and skates. Rays are live bearing (viviparous) while skates are egg laying (oviparous) Chimaeras are also known as ghost sharks, ratfish, spook fish and rabbit fishes.

Examples of Cartilaginous Fishes from literature (Figure 1-6) (Table 2).

Table 2: Fixed Cost Budgetary analysis of Dried Fish Air Sac marketing in Oron.

\begin{tabular}{|c|c|c|c|}
\hline Item & Total cost for all respondents (\$) & Percentage of Total Costs (TC) & Percentage of Total Fixed Costs (TFC) \\
\hline A. Fixed cost & & & \\
\hline Basin & $57,000.00$ & 2.26 & 10.05 \\
\hline Bags & $4,600.00$ & 0.18 & 0.81 \\
\hline Shop Rent & $235,970.00$ & 9.35 & 41.6 \\
\hline Knife/trays & $89,150.00$ & 3.53 & 15.72 \\
\hline
\end{tabular}




\begin{tabular}{|c|c|c|c|}
\hline Refrigerator/Generator & $180,450.00$ & 7.15 & 31.82 \\
\hline Total Fixed Cost (TFC) & $567,170.00$ & 22.47 & 100 \\
\hline Source: Field Study 2018 & & & \\
\hline
\end{tabular}

\begin{tabular}{|l|l|}
\hline & \\
\hline Figure 1: The Blue Shark. & \\
\hline
\end{tabular}
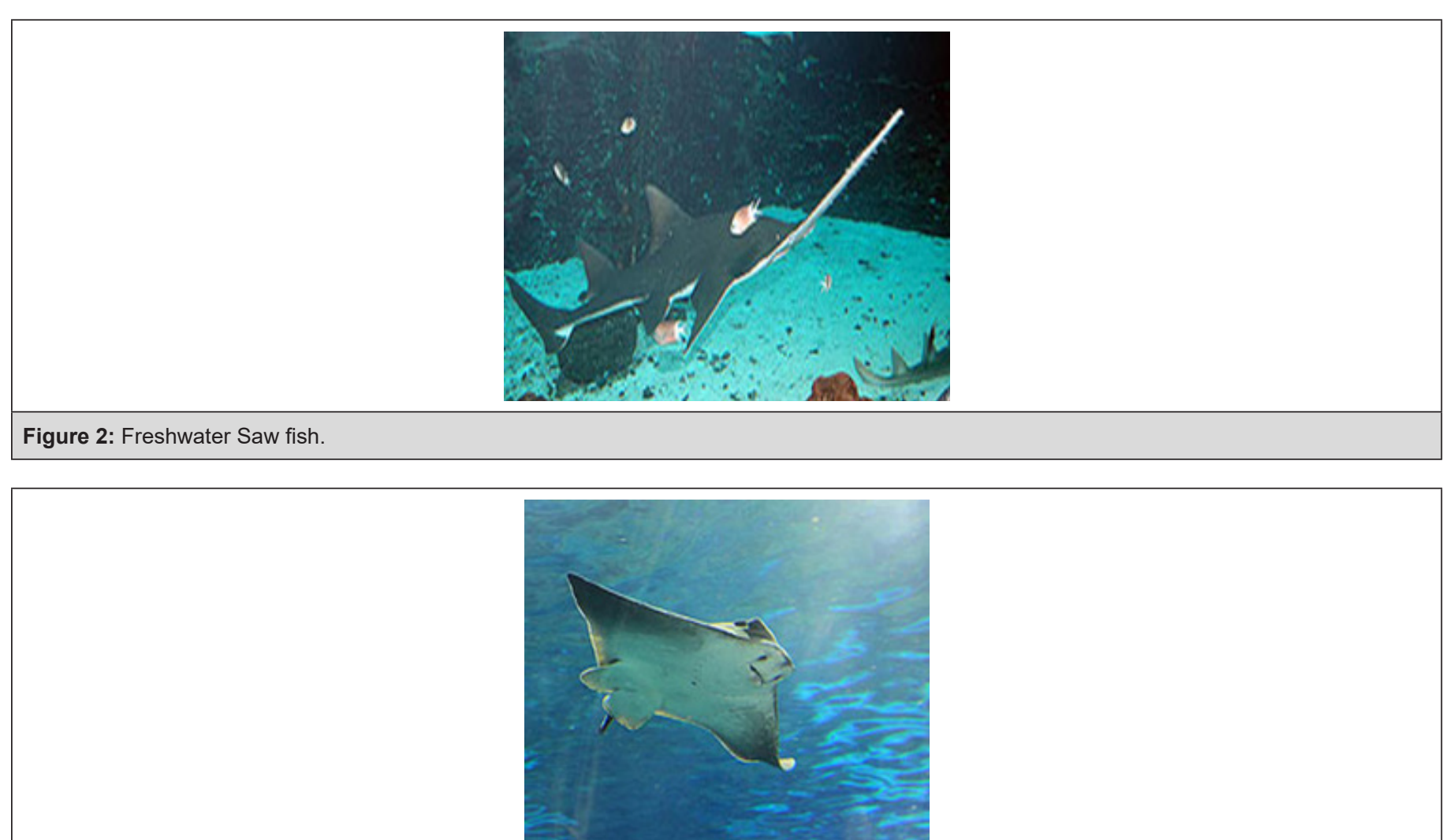

Figure 3: The Skate

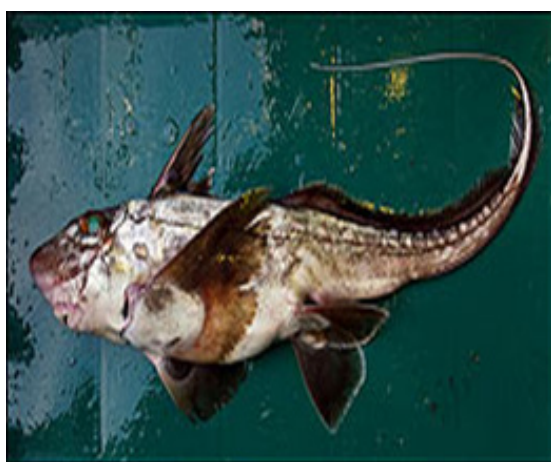

Figure 4: The Dark Ghost Shark (Chimaera). 

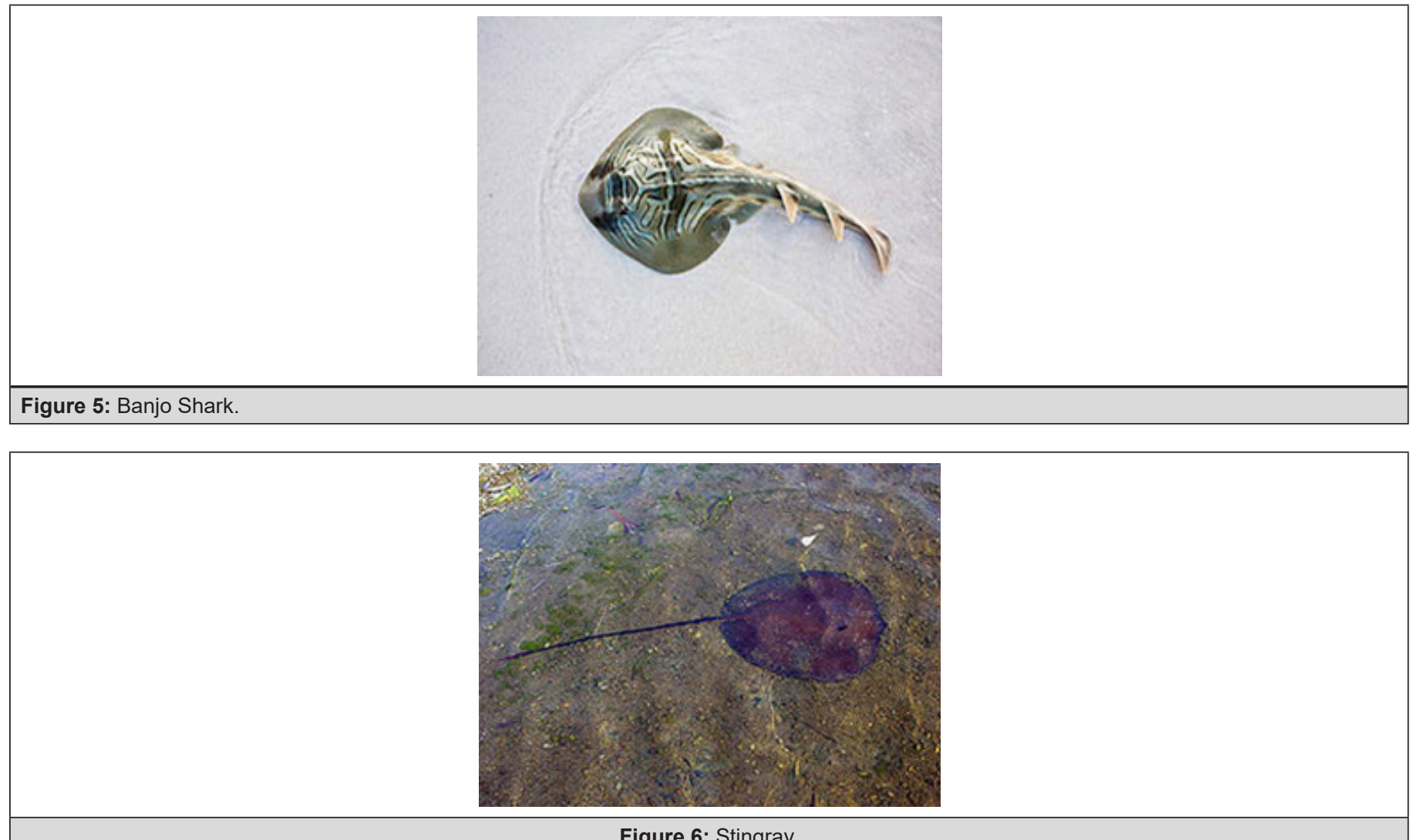

Figure 6: Stingray.

\section{Budgetary Cost and Return Analysis of Marketing Dried Fish Air Sacs}

Budgetary analysis of fixed cost of dried fish air sac marketing shows that shop rent takes $41.60 \%$ and $9.35 \%$ of the Total Fixed Cost (TFC) and Total Cost (TC) respectively. This is expected because field studies reveal that average monthly rent of a shop was

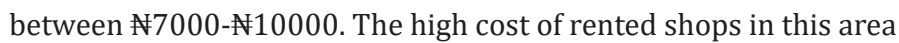
is not unconnected with the smuggling business around this area as most of the shops were used as warehouses for the smuggled goods. Refrigerator/generator constitutes $7.15 \%$ of the total costs and $31.82 \%$ of the Total Fixed Cost (TFC) respectively. Knife and trays constitute $3.53 \%$ and $15.72 \%$ of the total cost e total fixed cost respectively. Basin constitute $2.26 \%$ of total cost and $10.05 \%$ of the Total Fixed Cost (TC) respectively while bags constitute $0.18 \%$ of total cost and $0.81 \%$ of the Total Fixed Cost (TC) respectively. The study reveals that fixed cost of $N 567,170.00$ is only $22.47 \%$ of the total cost of marketing of the dried fish's air sac in the study area. This invariably means that in dried fish air sac marketing, the budgetary fixed cost is about one quarter (1/4) of the total budgetary cost of it (Table 3).

\begin{tabular}{|c|c|c|c|}
\hline Table 3: Variable Cost budgetary analysis of Dried Fish Air Sac marketing in Oron. \\
\hline Item & Total cost for all Respondents (N) & Percentage of Total Costs (TC) & Percentage of Total Variable Costs (TVC) \\
\hline Variable Cost & & & \\
\hline Fish Price & $1,603,000.00$ & 63.5 & 81.89 \\
\hline Labor /Drying & $209,930.00$ & 8.32 & 10.72 \\
\hline Processing cost & $40,022.00$ & 1.59 & 2.04 \\
\hline Storage & $85,658.00$ & 3.39 & 4.38 \\
\hline Water & $18,810.00$ & 0.75 & 0.96 \\
\hline Source: Field study, 2018 & & & \\
\hline
\end{tabular}

Budgetary analysis of variable cost of dried fish air sac marketing shows that fish price took $63.5 \%$ of the total cost and $81.89 \%$ of the Total Variable Cost (TVC) of marketing dried fish air sac. This is expected because not all the fish's air sacs are needed and sold. The high cost of the chosen fishes in this area is not unconnected with this specialised and highly valued and demanded organ of these fishes. Labour/drying constituted $8.32 \%$ of the TC and $10.72 \%$ of the TVC while storage and processing costs constituted $3.39 \%$ and $4.38 \mathrm{bulk}$ real cost of marketing of dried fish air sac in the study area is on the variable costs and the variable costs was $77.53 \%$ 
( $11,957,420.00$ ) of the total budgetary allocation for the entire marketing process.

Table 4 shows the profitability of dried fish air sac marketing ascertained using budgetary analysis. The total cost of marketing dried fish air sac during the period of the study was $\$ 2,524,590.00$ and the total revenue of $\mathrm{A} 3,413,591.00$ was realized; hence a net profit of $\$ 889,001.00$ was realized from sales of dried fish air sac by the marketers between the periods. The net profit shows that dried fish air sac marketing in the study area was profitable. The finding agrees with Oyieng et al. [5] who reported that fish marketing is a profitable enterprise in Akwa Ibom State. Oyieng et al. [5] also reported that dried fish trading is a significant economic livelihood of people in the rain forest and derived savanna ecological zones of Nigeria. The marketing efficiency of dried fish air sac marketing in the study area was 135.2 and operationally 1.74 as shown in Table 4. This implies that dried fish air sac market in the study area was efficient [6-15].

\begin{tabular}{|c|c|c|}
\hline Table 4: Estimation of Profit and Cost of dry Fish Air Sac. \\
\hline S/N & Estimation of Profit and Cost & Values (N) \\
\hline 1 & Total Fixed Cost & $1,967,170.00$ \\
\hline 2 & Total Variable Cost & $2,524,590.00$ \\
\hline 3 & Total Cost = TFC+TVC & $3,413,591.00$ \\
\hline 4 & Total Revenue (TR) & 899,001 \\
\hline 5 & Net Profit (Л) & $1,456,171.00$ \\
\hline 6 & Gross Margin (GM) & 135.2 \\
\hline 7 & Marketing Efficiency (ME) & 1.74 \\
\hline 8 & Operational Efficiency & \\
\hline
\end{tabular}

\section{Conclusion and Recommendations}

The research results show that $51.67 \%$ of the traders were of $31-40$ years while $80 \%$ of them were married, $55 \%$ of them were with house-hold size of between 4-6 persons and 50\% were at least with primary education. It shows that $53.33 \%$ of them apiece had trading experience of between 5-10 years with petty trading as their secondary occupation while $55 \%$ made a monthly income of about N21,000 - N30,000. Field survey shows that only cartilaginous fishes air sacs were preferred. They were found to be primarily marine fishes, having endoskeleton made from cartilage instead of bones and exoskeleton made of placoid (very small denticles coated with lots of sharp enamel). Their buccal cavities are ventrally positioned while their tail fins are heterocercal. They have five gills instead of operculum and fertilize their eggs through internal mechanisms. Among them as the literature enumerates are; the Rays, Skates, Sharks and Chimaeras (ghost sharks) [16-30].

Budgetary analysis of fixed cost of dried fish air sac marketing shows that shop rent has the highest percentage of $9.35 \%$ of the total cost of marketing dried fish air sac and $41.60 \%$ of the total fixed cost. Refrigerator/generator had $7.15 \%$ and $31.82 \%$, knife and trays had $3.53 \%$ and $15.72 \%$, basins constituted $2.26 \%$ and $15.72 \%$ of the total cost and total fixed cost respectively. The study reveals that the fixed cost of $5567,170.00$ was only $22.47 \%$ of the total cost of marketing of the dried fish's air sac in the study area.

Budgetary analysis of variable cost of dried fish air sac marketing shows that fish price has the highest percentage of $63.5 \%$ and $81.89 \%$ of the total cost and the total variable cost, labour/drying constituted $8.32 \%$ and $10.72 \%$, while storage was $3.39 \%$ and $4.38 \%$ and processing $1.59 \%$ and $2.04 \%$ TC and the TVC respective- ly [31-40]. The study reveals that variable cost of $N 1,957,420.00$ is only $77.53 \%$ of the total cost of marketing of the dried fish's air sac in the study area. Profitability of dried fish air sac marketing shows that the net profit was $\$ 889,001.00$ for the period with a marketing efficiency of 135.2 and operational efficiency of 1.74. This implies that dried fish air sac market in the study area was profitable and efficient.

Constraints shows a descending order of lack of storage facilities, poor marketing channels, high cost of drying price, price fluctuation, perishability and seasonality of the product, lack of capital/finance, lack of modern processing technologies, high cost of registration/selling permit and lack of relevant extension services were the most severe constraints to dried fish air sac marketing in rural areas of Akwa Ibom State. The study recommends the provision of storage and drying facilities for the processing of the fish air sacs and the provision of proper channel for the marketing of the processed products. It is equally recommended that the price of the product should be stable $[41,42]$.

\section{References}

1. Onu JI, Iliyasu HA (2008) An Economic Analysis of the Food Grain Market in Adamawa state, Nigeria. World Journal of Agricultural Science 4(5): 617-622.

2. IFAD/CBNRMP (2005) International Fund for Agricultural Development/Community Based Natural Resource Management Programme. Niger Delta Appraisal Report 231-239.

3. Daniels CB, Orgeig S, Sullivan LC, Ling N, Bennett MB, et al. (2004) The origin and evolution of the surfactant system in fish: insights into the evolution of lungs and swim bladders. Physiol Biochem Zool 77(5): 732749 .

4. Abbot, Mackham JP (1980) Agricultural Economics and marketing in the Tropics. Longman Ltd, London, UK. 
5. Teresa M (2009) A Tradition of Soup: Flavors from China's Pearl River Delta, North Atlantic Books, Atlantic Ocean p. 70.

6. Vaquita Recovery Team (2017) Extinction Is Imminent: New report from Vaquita Recovery Team (CIRVA).

7. Huxley J (1957) Material of early contraceptive sheaths. British Medical Journal 1(5018): 581-582

8. Adegeye AJ, Dittoh JS (1982) Essentials of Agricultural Economics. University of Ibadan, University Press, Ibadan, Nigeria pp. 252-258.

9. Adekanye TO (1988) A Rice Grading Scheme for Nigeria. In: Adekanye TO (editor). Readings in Agricultural Marketing Lagos, Longman Group Limited, London, UK.

10. Adekanye TO (2008) Marketing Margins for Food: Some Methodological Issues and Empirical Findings for Nigeria. Canadian Journal of Agricultural Economics 30(3): 333-344.

11. Akinieye A (2004) Hedonic Price Analysis to Guide in Breeding and Production of Livestock. SAGE Journal 44(2): 126-226.

12. Ali EA, Gaya HIM, Jampada TN (2008) Economic Analysis of fresh fish marketing in Maiduguri Gamboru Market and Kachallari Alau Dam landing site of North Eastern Nigeria. Journal of Agricultural Social Science 4(1): 23-26.

13. Blaxter JHS (1981) The Swim Bladder and Hearing. Hearing and Sound Communication in Fishes p. 67-71.

14. Bowen GA (2009) Document Analysis as a Qualitative Research Method Qualitative Research Journal 9(2): 27-40.

15. Fagbohun AE (2012) Socio-Economic Analysis of Fish Processing and Marketing in Ogun Waterside Local Government, Ogun State Nigeria. A Project Report Submitted to Department of Aquaculture and Fisheries Management College of Environmental Resources Management Federal University of Agriculture, Abeokuta, Nigeria

16. FAO (2005) FAO/World fish Center Workshop on Interdisciplinary approaches to the assessment of Small-Scale Fisheries. p. 1-18.

17. FDF (2005) Report of Presidential Committee on Fisheries and aquaculture Development. Consolidated Repot 1: 2005.

18. Harden Jones (1967) Fish Migration. Science 163(3870): 923.

19. Hakkansson F, Walaszewski G (2005) Morphological Characteristics of Eighteen Lakes Fishes. Marine Environmental Research 60(2): 221-243.

20. Kilarski P (2012) Biology and Cultures of Percid Fishes: Principles and practices.

21. Kohls RL, Downey WD (1972) Marketing of Agricultural Products. Macmillan Publishing Company New York, USA pp. 225-229.

22. Kohls RL, Uhl JN (1980) Marketing of Agricultural Products. Macmillan Publishing Company, New York, USA pp. 225-229.

23. Kotler AS (1989) Market management: Analysis planning implementing and control $\left(7^{\text {th }}\right.$ edition) prentice hall inter inc.

24. Kotler P, Armstrong G (2008) Principles of Marketing. ( $8^{\text {th }}$ edition) Upper Saddle River, Prentice Hall, New Jersey, USA.

25. Ladich P (2012) Auditory Evoked Potential Audiometry in Fish.

26. Lechner O, Ladich P (2008) Mating Tactics and Male-Male Courtship in the Lek-Breeding Cichld Oremchromis. Journal of Biology 52(6): 78.
27. Longo R, Pearce U, Grail O (2013) Massive Genemic Variation and Strong Selection of Arabidopsis. BMC Health Sciences Research 13(158): 34-67.

28. Matiya G, Wakabayashi Y, Takenouchi N (2005) Factors Influencing the Prices of Fish in Central Region of Malawi and its Implications on the Development of Aquaculture in Malawi. Journal of Applied Sciences 5(8): 1424-1429.

29. Mc Carthy EJ, Perreault WD (1991) Basic Marketing: A Global-Managerial Approach (13 ${ }^{\text {th }}$ edition) Irwin/Mc Graw-Hill, Boston, New York, USA.

30. National Population Commission (2006) Population and Housing Census of the Federal Republic of Nigeria. Analytical Report at the National Population Commission, Abuja, Nigeria.

31. Nwaru RS, Obina QS, Nonso PF (2011) Impact of Migrant Remittances on Welfare of Arable Crops Farmers. Human Ecology Review 18(2): 159-166.

32. Nwabunike MO (2015) The Socio-Economic Characteristics of Fish Marketers in Abakaliki Metropolis of Ebonyi State. International Journal of Animal Health and Livestock Production Research 1(1): 28-36.

33. O'Leary Z (2014) The essential guide to doing your research project ( $2^{\text {nd }}$ edition) Thousand Oaks, CA: SAGE Publications, India.

34. Olukosi JO, Isitor SU (1990) An introduction to Agricultural marketing and price: principles and applications. Living books series GU publications Abuja, Nigeria pp. 115.

35. Omofonwam EI, Ashaolu OF, Ayinde IA, Fakoya EO (2013) Assessment of palm wine market in Edo State, Journal of Science and Multidisciplinary Research 5(2): 141-151.

36. Oyieng EP, Charo HK, Kahi AK, Ojango JMK (2013) Characterization of fish production and marketing practices under small-holder fish farming systems of Eastern Kenya. Livestock Research for Rural Development 25(2): 2013.

37. Tomek WG, Robinson L (1981) Agricultural product prices ( $2^{\text {nd }}$ edition) Cornel University press Ihaca, New York, USA.

38. Scott WR (1995) Institutions and Organizations, Ideas, Interest and Identities. Dans Management 17: 136-140.

39. Butler WR (2000) Nutritional Interaction with Reproduction Performance in Dairy cattle. Animal Reproduction Science 2(61): 449-457.

40. Webb JB (1998) Leterophysic connection; a unique link between the Swim bladder and the Lateral line Systemin Chaeton (perciformchaodontidae) CoEIA, Saudi Arabia 998(4): 1032-1036.

41. Webb JF, Smith WL, Ketten DR (2006) Laterophysic connection of swim bladder fishes of butterfly fishes in the genus Chaeton (perciformes: chaetodontidae). Journal of Morphology 267(11): 1338-1355.

42. Zheng W, Wang Z, Collins JE, Andrew R, Stemple D, et al. (2011) Comparative Transcriptome Analysis Indicate and Mammalian Lung. Plosone $6(8)$. 